\title{
Bireylerin Yatırım Kararlarında Maruz Kaldığı Anomali ve Hevristikler Üzerine Ampirik Bir Çalışma
}

\author{
An Empirical Study of Individuals' Investment Decision Anomalies and \\ Heuristics
}

\section{Batuhan MEDETOĞLU1 ${ }^{\mathbb{D}}$, Arif SALDANLI² ${ }^{\mathbb{D}}$}

\section{öz}

Davranışsal finans, bireylerin yatırım kararı verirken birtakım psikolojik, dışsal ve çeşitli faktörler nedeniyle rasyonel olamadığını ve yatırım kararlarını doğru şekilde veremediğini savunmaktadır. Bu çalışma, bireysel yatırımcıların yatırım kararlarında hangi faktörlere maruz kaldığının tespiti amacıyla gerçekleştirilmiştir. Çalışma kapsamında 532 kişiye anket çalışması uygulanmıştır. Analizler SPSS (The Statistical Package for the Social Sciences) programında gerçekleştirilmiştir. Anket cevapları ilk olarak faktör analizine tabi tutulmuştur. Ardından güvenilirlik analizi yapılarak katılımcıların yatırım kararlarında en çok hangi faktörlerin etkili olduğunun tespiti sağlanmıştır. Çalışmada faktörlerin güvenilirlik düzeylerine bakıldığında ise belirlenen sınırların üzerinde olduğu gözlemlenmektedir. Faktörler arasında anlamlı ve pozitif yönlü ilişkinin varlığı da tespit edilmiştir. Elde edilen sonuçlara göre yatırımcıların kararlarında etkilendiği faktörler üç grupta toplanmıştır. Bu faktörler dışsal faktörler ve sürü davranışı, bilişsel yanılsamalar, demografik ve sosyoekonomik özellikler şeklinde tespit edilmiştir. Dışsal faktörler ve sürü davranışı yatırımcılardan bağımsız gerçekleşen durumları, bilişsel yanılsamalar yatırımcıların psikolojik faktörlerden etkilenmelerini, demografik ve sosyoekonomik faktörler ise yatırımcıların özelliklerinden kaynaklanan tutumlarını göstermektedir. Çalışma sonucunda, yatırımcıların yatırım kararlarına etki eden durumlar üç faktörde toplanarak, yatırımcı davranışlarının açıklandığı bulgusu elde edilmiştir. Çalışma sonucunda elde edilen faktörlerin, bireylerin yatırım esnasında maruz kaldığı durumları yansıttığı ve açıkladığı bulgusuna ulaşıımıştır. Çalışmanın sınırlıııkları anket uygulanan kişilerin büyük bir çoğunluğunun benzer yaş aralığında olması gösterilebilir. Daha sonra gerçekleştirilecek çalışmalarda ise farklı gruplar üzerinde çalışma gerçekleştirilmesi önerilmektedir.

Anahtar Kelimeler: Finans, Davranışsal finans, Yatırım kararları, Anomaliler, Hevristikler

Jel Sınıflaması: G11, G40, G41

\section{DOI: 10.26650/JEPR936253}

\section{'Öğretim Görevlisi, İstanbul Ayvansaray Üniversitesi, Finans Bankacılık ve Sigortacılık Bölümü, İstanbul, Türkiye \\ ${ }^{2}$ Doç. Dr. İstanbul Üniversitesi, İktisat Fakültesi, İ̧letme Bölümü, İstanbul, Türkiye}

ORCID: B.M. 0000-0002-8400-1232; A.S. $0000-0001-9990-9510$

\section{Sorumlu yazar/Corresponding author: Batuhan MEDETOĞLU, \\ Öğretim Görevlisi, İstanbul Ayvansaray Üniversitesi, Finans Bankacılık ve Sigortacılık Bölümü, İstanbul, Türkiye \\ E-posta/E-mail: \\ batuhanmedetoglu@ayvansaray.edu.tr}

Başvuru/Submitted: 13.08.2021

Revizyon Talebi/Revision Requested: 9.10.2021

Son Revizyon/Last Revision Received: 10.10.2021

Kabul/Accepted: 22.10 .2021

Atıf/Citation: Medetoglu, B., \& Saldanli, A. (2022). Bireylerin yatırım kararlarında maruz kaldığı anomali ve hevristikler üzerine ampirik bir çalıșma. Iktisat Politikası Araștırmaları Dergisi - Journal of Economic Policy Researches, 9(1), 53-74.

https://doi.org/10.26650/JEPR936253 


\begin{abstract}
Behavioral finance argues that individuals are not rational while making investment decisions due to some psychological, exogenous, and other factors. As a result, they end up making poor financial decisions. This study was conducted to determine factors that individual investors are exposed to while making investment decisions. A questionnaire was handed over to 532 participants as part of the study. The Statistical Package for the Social Sciences (SPSS) program was used to conduct the analysis. Questionnaire responses were first subjected to factor analysis, and later, reliability analysis was conducted to determine which factors were the most effective in participants' investment decisions. The reliability levels of the factors in the study were observed to be above the determined limits. The factors were shown to exhibit a significant and positive relationship. According to the results obtained, factors that affect investor decisions were grouped into three categories, namely, exogenous factors and herd behavior; cognitive illusions; and demographic and socioeconomic factors. Exogenous factors and herd behavior demonstrate situations that occur independently of investors, cognitive illusions demonstrate how psychological factors affect investors, and demographic and socioeconomic factors demonstrate how characteristics influence investors' attitudes. Consequently, situations that affect investment decisions of investors were also grouped under three factors and findings concerning investor behaviors were explained. It was determined that the factors obtained in the study reflect and explain the situations that individuals are exposed to while making investment decisions. A majority of the participants are in the same age range, which is one of the study's limitations. The use of diverse age groups in future research is suggested.
\end{abstract}

Keywords: finance, Behavioral Finance, Investment decisions, Anomalies, Heuristic

Jel Classification: G11, G40, G41

\title{
EXTENDED ABSTRACT
}

Traditional finance theories argue that individuals are rational and make investment decisions without being subjected to any deception. Alternatively, behavioral finance suggests that individuals' investment decisions are influenced by psychological, exogenous, and other factors, and thus, irrational preferences may be involved. This study aims to determine the factors that affect investment decisions of investors. Homo economicus is a Latin word that means "economic or economic person." "The Wealth of Nations" written by Adam Smith in 1776 marks the beginning of the classical economics concept and homo economicus. Traditional finance theories accept individuals as rational and consider individuals as homo economicus, i.e., as economic people. Hall (1978) assumes that in his random walk theory, individuals make decisions with rational expectations. Fama (1970) accepts the random walk theory as one of the most basic assumptions based on which the efficient markets hypothesis is formulated. Fama defines the efficient market as the market in which information is fully reflected in current asset prices. The Expectation Theory put forward by Kahneman and Tversky (1979) criticizes the Expected Utility Theory, founded by Daniel Bernoulli, for not taking into account the behavior of individuals. Factors influencing investment decisions can be grouped under three headings, namely, exogenous factors and herd behavior; cognitive illusions; and demographic and socioeconomic factors.

The factors to which investors are exposed were determined by a questionnaire method used in this study. Questionnaires, consisting of 25 questions, were sent to the participants 
online and their responses were collected via Google Forms. In the study, a 5-point Likert scale was preferred because it is common in the literature. Responses of 532 participants were examined by subjecting them to various analyzes in the SPSS program for determining factors influencing investment decisions. Questionnaire responses were first subjected to factor analysis. Then, by performing a reliability analysis, it was ensured that the most influential factors were determined. It was observed that the reliability level of factors was above the determined limits. The existence of a significant and positive relationship between the factors was also determined. Within the scope of the study, the analysis started with 25 questions. One test question was not included in the analysis. Seven questions were not analyzed as their factor load was insufficient, and thus, the analysis was completed using 17 questions. The measures to evaluate the quality of factor analysis are KMO coefficient, Bartlett's test, and Sig value. Hair et al. (2010) reported that KMO should be at least 0.50 , and the KMO value in this study is 0.91 , which is well above the determined threshold. When the total variance values of the study are examined, it is observed that all factors explain $51.69 \%$ of the variance. Moreover, when the literature is reviewed, it is observed that the total variance value explained is sufficient.

Reliability analysis is a type of analysis that shows the accuracy and consistency of a study. As the Cronbach's alpha coefficient approaches 1, the reliability of the measurement tool increases. It is stated that the level of the measurement tool should be 0.70 and above. In this study, 17 questions were analyzed, and the Cronbach's alpha coefficient was found to be 0.876 . Considering this result, it can be stated that the study is at a reliable level. It was also observed that 17 questions are distributed to three factors. These factors express the anomalies and heuristics that affect individuals decision-making ability. The first factor affecting individuals' investment decisions is exogenous factors and herd behavior. Exogenous factors are factors that arise independently of investments yet have an impact on individuals. Herd behavior appears as a behavior that affects individuals who are exposed to them. The second factor is cognitive illusions that affect individuals' psychological behavior as well as their investment decisions. The third factor is demographic and socioeconomic factors of investors. Characteristics such as age, gender, and income status also emerge as important determinants influencing investment decisions. It can be concluded that as investment decisions are influenced by these three factors, investors are unable to think rationally and make logical investment decisions. The study's findings were applied to similar age groups, which can be considered as a limitation. It is recommended that further studies should to be conducted with different age and income groups. 


\section{Giriş}

Geleneksel finans teorileri, bireylerin rasyonel olduğunu ve yatırım kararlarında herhangi bir aldanmaya maruz kalmadan kararlar aldıklarını savunmaktadır. Davranışsal finans ise bireylerin yatırım kararlarında psikolojik, dışsal ve çeşitli faktörlerin altında kararlar verdiklerini ve dolayısı ile rasyonel olmayan tercihlerinde söz konusu olabileceğini öne sürmektedir. Çalışmanın amacı, yatırımcıların vermiş olduğu yatırım kararlarında etkili olan faktörlerin tespitini sağlamaktır. Çalışma üç bölümden oluşmaktadır. Birinci bölümde davranışsal finans kavramı, anomaliler ve hevristikler açıklanmıştır. İkinci bölümde literatür taraması yapılmış ve gerçekleştirilen çalışmalar gösterilmiştir. Üçüncü bölümde ise gerçekleştirilen anket çalışmasına ait veriler analiz edilmiş ve bulgular sunulmuştur.

\section{Kavramsal Çerçeve}

Homo Economicus, latince kökenli bir kelime olup, ekonomik ya da iktisadi insan anlamına gelmektedir. Adam Smith tarafından 1776 yılında yazılan 'Ulusların Zenginliği' eseri, klasik iktisat ve homo economicus kavramının başlangıcı kabul edilmektedir (Mola, 2021, s. 21). Geleneksel finans teorilerine göre de bireylerin rasyonel tercihlerde bulunmaları temel varsayım olarak kabul edilmektedir. Bireylerin rasyonel olmasının da piyasalara olumsuz bir etkisinin olmadığı savunulmaktadır (Tufan \& Sarıçiçek, 2013).

Geleneksel finans teorileri, bireyleri rasyonel olarak kabul etmekte ve bireyleri homo economicus yani ekonomik insan olarak kabul etmektedir. Hall (1978), rassal yürüyüş teorisinde, bireylerin vermiş olduğu kararları, rasyonel beklentiler ile verdiğini varsaymaktadır. Ekonomide ve gelir düzeyinde beklenmedik gelişmeler olmadıkça, kararların ortalama olarak tahmin edilebileceğini öne sürmüştür. Bireylerin tüketimlerini tahmin edebileceğinin yanında dayanıksız tüketim mallarının da tesadüfi yürüyüş sergilediği savunulmuştur. Beklenmedik bir olay olmadığı sürece, cari dönemin, geçmiş dönemler 1şığında tahmin edilebileceği öne sürülmüştür (Hall, 1978).

Piyasa etkinliği kavramından, 1900 yılında ilk kez Bachelier tarafından bahsedilmiş ve kavram tam manasıyla Fama (1970) tarafindan ortaya konulmuştur. Etkin Piyasa Hipotezinde bahsedilen etkin piyasada, yatırımcıların piyasadaki tüm bilgilere eksiksiz biçimde ulaştığı ve normal üstü getiri elde edilemediği savunulmaktadır (Gümüş \& Bektur, 2019,s.60-61). Fama (1970), geçekleştirmiş olduğu çalışmasında rassal yürüyüşü, Etkin Piyasalar Hipotezinin dayandığı en temel varsayımlardan biri olarak kabul etmiştir. Fama etkin piyasayı, bilginin mevcut varlık fiyatlarına tamamen yansıdığı piyasa şeklinde tanımlamıştır. Etkin bir piyasadan bahsetmek için de işlem maliyeti olmaması, bilgiye tam ulaşma ve ekonomik birimlerin varlıklara yönelik görüş birliği içinde olduğu varsayımlarının olması gerektiği savunulmuştur. Etkin Piyasa Hipotezine göre piyasalar zayıf formda etkin, yarı 
güçlü formda etkin ve güçlü formda etkin olmak üzere 3'e ayrılmaktadır. Zayıf formda etkinlik, geçmiş fiyat hareketliliklerinin varlıklara yansıdığını, dolayısıyla geçmiş fiyat bilgileriyle aşırı kazanç sağlanamayacağını öne sürmektedir. Yarı güçlü formda etkinlik, halka açıklanmış tüm bilgilerin piyasa fiyatlarına yansıdığı piyasa türüdür. Teknik analizle yarı güçlü formda etkin piyasalarda normal üstü getiri sağlamak mümkün değildir. Güçlü formda etkin piyasalarda ise bütün bilgilerin fiyatlara yansıdığı dolayısıyla ortalama üstü getiri elde edilmesinin mümkün olmadığı savunulmaktadır (Fama, 1970).

Kahneman ve Tversky tarafindan 1979 yılında ortaya atılan Beklenti Teorisi, beklenen fayda teorisini bireylerin davranışlarını dikkate almadığı yönüyle eleştirmiştir. Bireylerin almış olduğu kararlarda ve gerçekleştirdiği faaliyetlerde, psikolojik faktörlerden etkilendiği dolayısıyla irrasyonel davranışlar sergilendiği savunulmuştur. Piyasada işlem yapan karar vericilerin tamamının rasyonel olmadığı ve çeşitli psikolojik faktörlere maruz kalarak rasyonelliğini koruyamadığı savunulmaktadır. Gerçekleştirilen eleştirilerin bir diğeri ise bireylerin sistematik olarak Bayes kuralını ihlal ettiğidir. Beklenti teorisi, bireylerin belirsizlik altında karar alırken, bu kararları beklenen faydaya göre almadığını savunmaktadır (Kahneman \& Tversky, 1979).

Risk içeren durumlarda bireylerin risk almaktan kaçınarak yanlış kararlar alabileceği öne sürülmüştür (Türkmen Müldür, 2018, s. 39). Davranışsal finans, yatırımcıların yatırım kararı verirken rasyonel olmadığını savunmakta ve yatırımcıların rasyonel olamama sebeplerinin de birtakım anomali ve hevristiklerden kaynaklandığını savunmaktadır. Yatırımcıların etkilendiği çeşitli önyargı ve yanılsamalar belirlenerek, yatırımcıların rasyonel olamama sebepleri açıklanmaktadır (Korkmaz \& Ceylan, 2017). Davranışsal finans temelde psikoloji ve ekonomi biliminin birleşmesinden ortaya çıkmıştır. Bireylerin psikolojik ve birtakım diğer faktörler nedeniyle yanlış kararlar verdikleri savunulmakta ve rasyonellikten sapma nedenleri açıklanmaktadır (Aren, 2018). Dolayısıyla bireylerin, yatırım kararı verirken çeşitli faktörlere maruz kaldığı ve bu faktörlerin etkisiyle yanlış kararlar vererek piyasa dengesini bozduğu savunulmaktadır. Davranışsal finansa göre bireyler kimi zaman yanlış kararlar alarak kimi zaman da doğru bilgilerden yanlış çıkarımlar yaparak ve ağırlıklı olarak da bilişsel hatalara maruz kalarak yanlış finansal kararlar almaktadır (Fırat \&Kurtoğlu, 2014, s. 96).

Yatırımcıların, yatırım kararlarında maruz kaldığı etkenler üç başlık altında toplanabilir. $\mathrm{Bu}$ başlıkların ilki yatırım kararlarını etkileyen bilişsel önyargılardır. İkinci başlık demografik ve sosyoekonomik faktörler ve üçüncü başlık ise dişsal faktörler olarak gösterilmektedir. Başlıklara ek olarak yatırımcıların kararlarını etkileyen önemli bir kavram olan sürü davranışının da yatırım kararlarında etkili bir faktör olduğu savunulmaktadır (Korkmaz \& Ceylan, 2017). Yatırımcıların yatırım kararlarını etkileyen bilişsel önyargılar, 
sezgisel ve zihinsel olmak üzere ikiye ayrılmaktadır. Sezgisel yanılsamalar, yatırımcıların kestirme yollar kullanması nedeniyle yatırım kararlarında başarısız olmasını ifade etmektedir.

Sezgisel yanılsamalar aşağıdaki gibidir.

$\checkmark$ Aşina Olma Önyargısı

$\checkmark$ Aşırı Reaksiyon Önyargısı

$\checkmark$ İyimserlik Önyargısı

$\checkmark$ Kumarc1 Yanılgisı

$\checkmark$ Düşük Reaksiyon Gösterme

$\checkmark$ Aşırı Güven Hevristiği

$\checkmark$ Temsiliyet Hevristiği

$\checkmark$ Demirleme Etkisi

Sezgisel yanılsamalar, bireylerin kendine olan aşırı güveni, fiyat artış ve azalışlarında yüksek ya da düşük reaksiyon göstermesi, bir hisse senedinin temsil amaçlı seçilmesi ve iyimserlik gibi önyargılardan oluşmaktadır. Bireylerin bu önyargılar nedeniyle yatırımlarında rasyonel olamadığı savunulmaktadır.

Zihinsel yanılsamalar, bireylerin belirsizlik durumlarında kararlarında kullandığı kestirme yolları açıklamaktadır. Zihinsel yanılsamalar aşağıdaki gibidir.

$\checkmark$ Pişmanlıktan Kaçınma

$\checkmark$ Kayıptan kaçınma

$\checkmark$ Zihinsel Muhasebe

$\checkmark$ Çerçeveleme Etkisi

$\checkmark$ Kesinlik ve Sözde Kesinlik Etkisi

Zihinsel yanılsamalar, bireylerin yatırım kararlarında başvurduğu kestirme yolları açıklamaktadır. Yatırımcıların bu kestirme yolları kullanarak yatırımlarında rasyonel olamadığı savunulmaktadır.

Yatırımcılar sahip oldukları farklı demografik ve sosyoekonomik özellikleri nedeniyle yatırımlarında farklı kararlar vermektedir. Bu özellikler, yaş, cinsiyet, medeni durum, eğitim 
seviyesi, meslek, gelir seviyesi gibi sıralanabilmektedir. Gerçekleştirilen akademik çalışmalarda yaş arttıkça alınan riskin azalması, erkeklerin kadınlara göre yatırımlarda daha fazla risk alması, çocuk sayısının artmasıyla az riskli varlıklara yönelim gibi farklılıklar ortaya konulmuş ve demografik ve sosyoekonomik faktörlerin yatırım kararlarında önemli bir belirleyici olduğu savunulmaktadır.

Yatırımcıların kararlarını etkileyen bir diğer değişken dışsal faktörlerdir. Dışsal faktörler, kişinin psikolojisi ve özellikleri dışında gerçekleşen ve kişiyi yatırım kararları esnasında etkisi altına alan faktörlerdir. Bu faktörler nedeniyle yatırımcıların yatırım kararlarında rasyonel olamadığı savunulmaktadır. Yatırımcıların maruz kaldığı dışsal faktörler aşağıdaki gibi siralanabilir.

\section{$\checkmark$ Haftanın Günleri Etkisi}

$\checkmark$ Bayram, Kutsal Günler ve Tatil Etkisi

$\checkmark$ Hava Koşullarının Etkisi

$\checkmark$ Ay Etkisi

Yatırımcıların yatırım kararlarında önemli bir faktör olan sürü davranışı ise, aynı varlığa, aynı zamanda ve aynı yönde işlem yapılması şeklinde tanımlanabilir. Yatırımcıların herhangi bir analiz yapmaksızın gerçekleştirmiş oldukları bu yöntem, piyasada fiyat mekanizmasının doğru bir şekilde yani arz ve talebe göre oluşmasını engellemektedir. Sürü davranışı yatırımcıların kullanmış olduğu kestirme bir yöntemdir. Sürü davranışı rasyonel ve irrasyonel olmak üzere ikiye ayrılmaktadır. Rasyonel sürü davranışı, yatırımcıların yatırım araçları ile ilgili yeterli bilgiye sahip olmadıklarını düşündüğü durumlarda, diğer yatırımcıların yatırım kararlarını taklit ederek yatırım kararı vermeleri şeklinde tanımlanmaktadır. İrrasyonel sürü davranışı ise yatırımcıların bireysel kararlarını göz ardı ederek, diğer yatırımcıların yatırım kararlarını taklit etmesi sonucu ortaya çıkmaktadır. Rasyonel sürü davranışı bilgisel nedenlerle ortaya çıkarken, irrasyonel sürü davranışı yatırımcı psikoloji ile gerçekleşmektedir.

\section{Literatür Taraması}

Türkiye'de, bireysel yatırımcılar, borsa, kurumsal yatırımcılar ve çeşitli kesimler üzerine yatırım kararlarında hangi faktörlerin etkili olduğu, yatırımcı alışkanlıkları ve yatırımcıların yatırım kararlarındaki rasyonelliği gibi konularda çeşitli araştırmalar gerçekleştirilmiştir. Gerçekleştirilen çalışmalar aşağıda yer almaktadır.

Altay (2008) tarafından gerçekleştirilen çalışmada, 1997 - 2008 döneminde İMKB'de sürü davranışının analizi gerçekleştirilmiştir. Çalışmada hisse senedi beta katsayılarının 
yatay kesit değişkenliğine dayalı analiz gerçekleştirilmiştir. Çalışma sonucunda, sürü davranışının genel bir eğilim olduğu fakat Aralık 2003-Nisan 2004 ve Mayıs-Ekim 2006 döneminde piyasa yönünde sürü davranışı görülmediği sonucuna ulaşılmıştır.

Barak (2008) çalışmasında, aşırı reaksiyon anomalisinin Türkiye piyasasındaki geçerliliğini test etmiştir. Çalışmada Ocak 1992 - Aralık 2004 dönemleri arasında İMKB fiyat davranışı analiz edilmiştir. Çalışma sonucunda, geçmişte kazandıran hisse senetlerinden oluşturulan portföylerin takip eden dönemde kaybettirdiği, kaybettiren portföylerin ise kazandırdığı tespit edilmiştir.

Doğukanlı ve Ergün (2011) çalışmalarında, Aşırı Tepki Hipotezini İMKB özelinde incelemiştir. İMKB'de çeşitli endeksler üzerinde Temmuz 1998 ve Haziran 2008 dönemleri arasında kesintisiz işlem gören hisse senetlerinin aylık getirileri analiz edilmiştir. Çalışmada İMKB 30 dışındaki endekslerde Aşırı Tepki Hipotezi ve zıtlık stratejilerinin yararlığını destekler sonuçlara ulaşıldığı ifade edilmiştir.

Gümüş, Koç ve Agalarova (2013) çalışmalarında, Türkiye ve Azerbaycan'daki yatırımcıların yatırım kararı alırken birtakım önyargı, duygu, sezgi etkisi altında kalıp kalmadıkların tespitini amaçlamışlardır. Çalışmada 384 kişiye anket çalışması uygulanmış ve sonuçlar analiz edilmiştir. Analiz sonucunda, bireylerin medeni durumu, gelir ve eğitim seviyesi, yaş ve cinsiyetinin yatırım kararlarının farklılaşmaya neden olduğu tespit edilmiştir.

Küçük (2014) çalışmasında, birtakım psikolojik ve sosyolojik faktörlerin yatırım kararlarına etkisinin tespitini amaçlamıştır. Osmaniye ilinde 150 kişiye anket çalışması uygulanmıştır. Çalışma sonucunda, psikolojik ve sosyolojik faktörlerin yatırım kararlarında etkili olduğu sonucuna ulaşılmıştır.

Aydın ve Ağan (2016) çalışmalarında, bireysel yatırımcıların yatırım kararlarında etkilendiği psikolojik davranışları ortaya koymayı amaçlamıştır. Anket yöntemiyle araştırma yapılmış ve çeşitli istatistiksel testler uygulanmıştır. Çalışma sonucunda yatırımcıların davranışsal eğilimlerden etkilendiği ve irrasyonel davranışlar sergilediği bulgusu elde edilmiştir.

Gül, Ekşi ve Sürme (2017) çalışmalarında, yatırımcı davranışlarını incelemiştir. Yatırımcı davranışları aşırı güven, aşırı iyimserlik, pişmanlıktan kaçınma, kayıptan kaçınma ve temsil etme eğilimi olmak üzere beş boyutta ele alınmıştır. Çalışma sonucunda yatırımcı davranışının eğitim, firma yaşı ve mesleki tecrübeye göre farklılık gösterdiği sonucuna ulaşılmıştır.

Tekin (2018) çalışmasında, son yıllarda önemli bir kavram haline gelen davranışsal finans konusu ile ilgili literatürde yer alan bilgi ve çalışmaları derlemiştir. Davranışsal finansın unsuru olan önyargılar ve hevristikler açıklanmıştır. 
Özer ve Korkulutaş (2018) çalışmalarında, Erzincan ilinde bireysel yatırımcıların kararlarına etki eden faktörlerin belirlenmesini amaçlamışlardır. Çalışmada anket yöntemi kullanılmış ve sonuçlar analiz edilmiştir. Çalışma sonucunda ise yatırımcıların her zaman rasyonel davranışlar sergilemediği bulgusu elde edilmiştir.

Genç (2019) çalışmasında, Sakarya ilinde çalışan bireylerin, yatırım davranışlarını davranışsal finans çerçevesinde araştırmıştır. 250 kişiye anket çalışması uygulanmış ve anket sonuçları analiz edilmiştir. Çalışma sonucunda psikolojik faktörlerin bireylerin kararlarında etkili olduğu bulgusu elde edilmiştir.

Çetiner, Gökcek ve Gölbaşı (2019) çalışmalarında, yatırımcıların sergilediği irrasyonel davranışlar ile demografik değişkenler arasındaki bağımlılığı incelemiştir. Çalışmada 115 katılımcının analiz sonuçları değerlendirilmiştir ve analiz edilmiştir. Çalışma sonucunda, akılsal muhasebe değişkeni ile yaş grupları ve cinsiyet arasında; belirsizlikten kaçınma değişkeni ile de yaş grupları ve gelir düzeyleri arasında anlamlı ilişki olduğu tespit edilmiş ve bu ilişkiler dışında herhangi bir ilişkinin varlığı tespit edilememiştir.

\section{Araştırma Yöntemi ve Bulgular}

Çalışma, bireylerin yatırım yaparken hangi faktörlerin etkisi altında kalarak yatırım kararlarını verdiğinin tespiti amacıyla gerçekleştirilmiştir. Çalışmada faktörlerin belirlenmesi amacıyla yatırımcılara anket yöntemi uygulanmıştır. Anketler online olarak katılımcılara gönderilmiş ve yanıtları Google Forms üzerinden toplanmıştır. Çalışmada 5'li likert ölçeği kullanılmış ve çalışma 25 sorudan oluşmuştur. Çalışmaya ilişkin anket soruları, çalışma sonunda yer almaktadır (EK 1).

Anket çalışması 685 kişiye uygulanmıştır. Çalışmanın güven düzeyinin arttırılması amacı ile katılımcılara sınama sorusu sorulmuştur. Sınama sorusunda katılımcıların 'kesinlikle katılıyorum' seçeneğini işaretlemesi istenmiştir. Kesinlikle katılıyorum seçeneğini işaretlemeyen 138 katılımcının cevapları çalışmadan çıkarılmıştır. Ek olarak tüm sorulara aynı cevabı veren 15 katılımcının cevapları da çalışmadan çıkarılmış ve nihai olarak 532 katılımcının cevapları analize tabi tutulmuştur.

Katılımcılara ait cinsiyet, yaş aralığı, çalışma durumu, eğitim durumu, aylık kişisel gelir ve aylık kişisel gelir niteliği bilgileri aşağıda yer alan grafiklerde gösterilmektedir. 


\section{Grafik 1. Katılımcıların Cinsiyet Dağılımları}

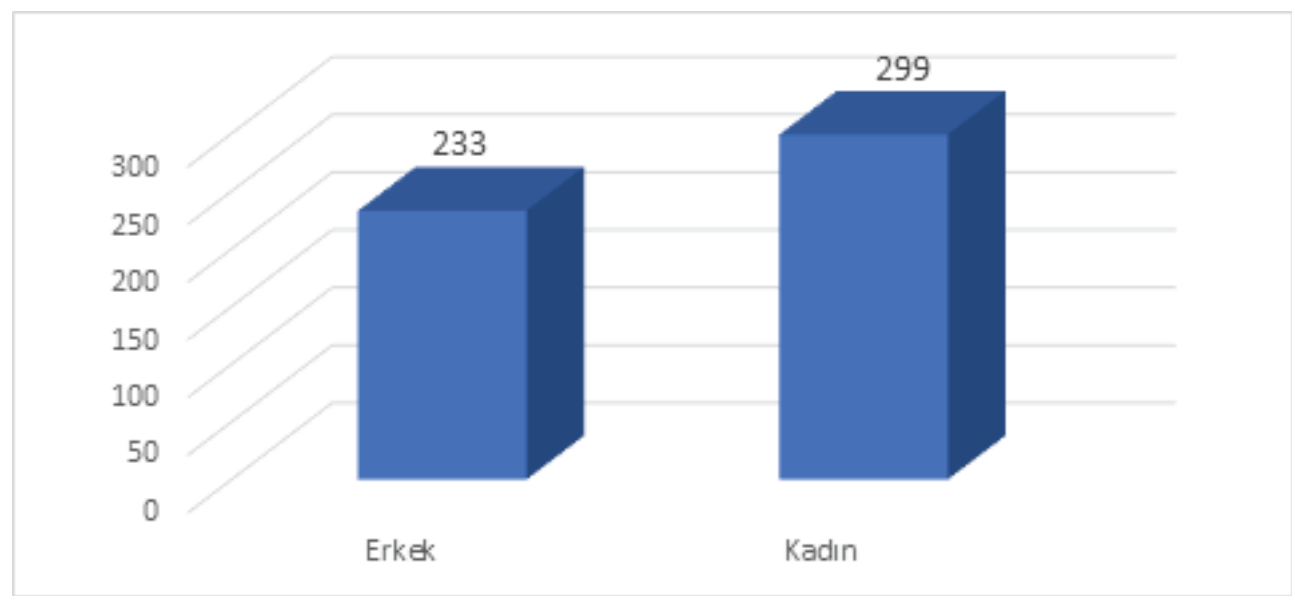

Çalışmaya katılan 532 kişinin \%56'sı kadın, \%44'ü ise erkek katılımcılardan oluşmaktadır. Kadın katılımcı sayısı 299, erkek katılımcı sayısı ise 233’tür. Kadınların erkeklere oranla çalışmaya daha fazla katılım gösterdiği gözlemlenmektedir.

\section{Grafik 2. Katılımcıların Yaş Dağılımları}

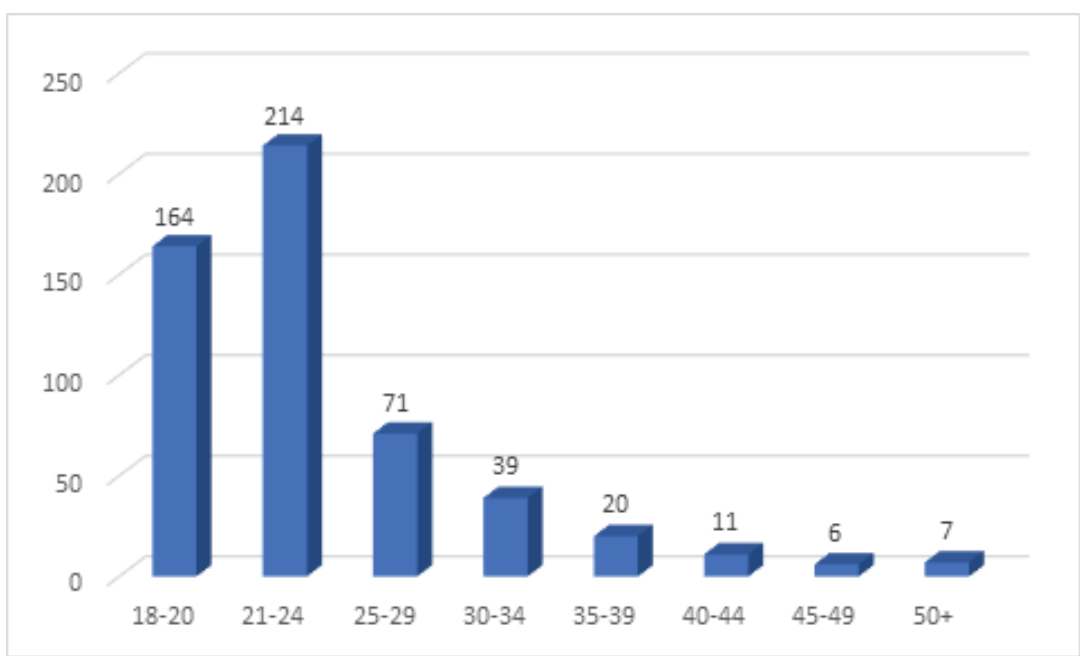

Katılımcıların, \%40'1 21-24 yaş aralığında olup, \%30'u ise 18-20 yaş aralığındadır. Çalışmaya katılan kişilerin yaklaşık \%70’i 18-24 yaş aralığında olan bireylerdir. 25-29 yaş aralığında katılım sağlayan kişiler \%13 olarak gerçekleşmiştir. Diğer yaş gruplarındaki katılım ise Grafik 2'de gösterilmektedir. 


\section{Grafik 3. Katılımcıların Çalışma Durumu}

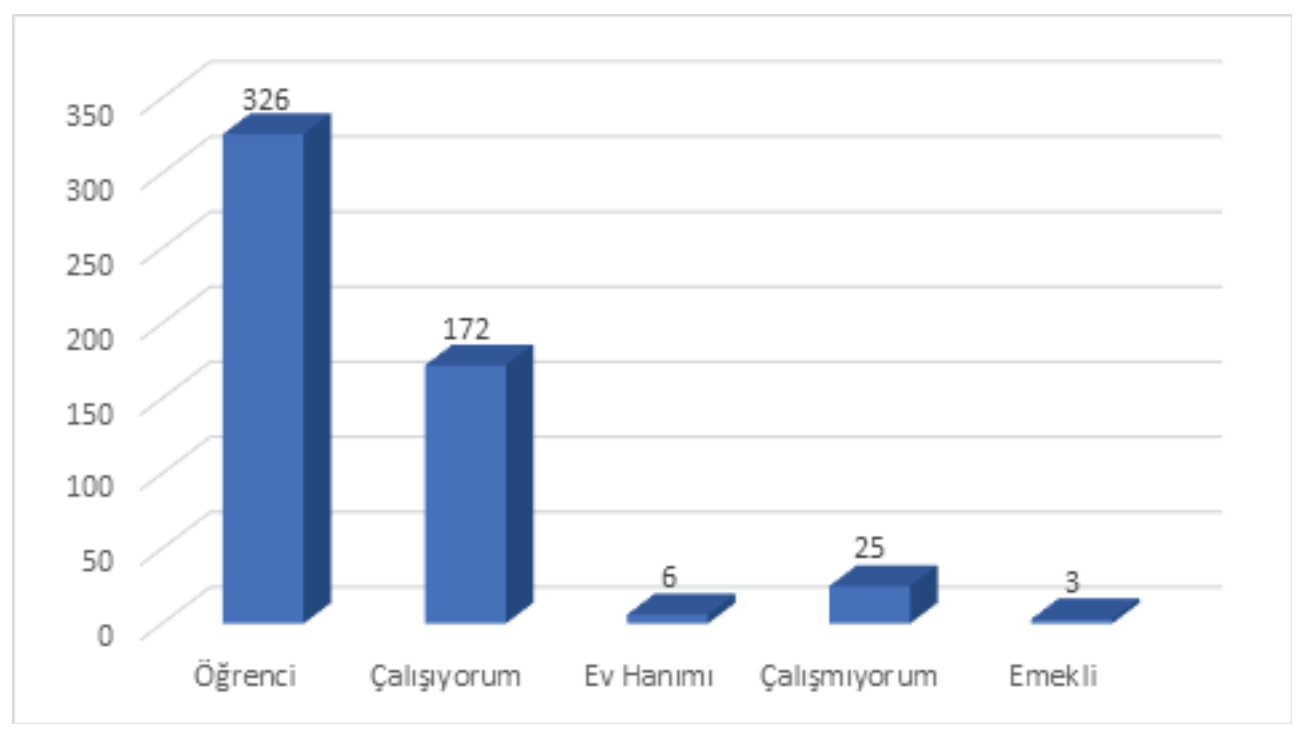

Katılımcıların çalışma durumuna bakıldığında, \%61 öğrenci, \%32 çalışıyor, \%5 çalışmıyor şeklinde bir dağılım görülmektedir. Diğer katılımcıların çalışma durumu Grafik 3 ’te yer almaktadır. Çalışmanın önemli bir kısmına katılım sağlayan kişilerin öğrenci olduğu görülmektedir.

\section{Grafik 4. Katılımcıların Eğitim Durumu}

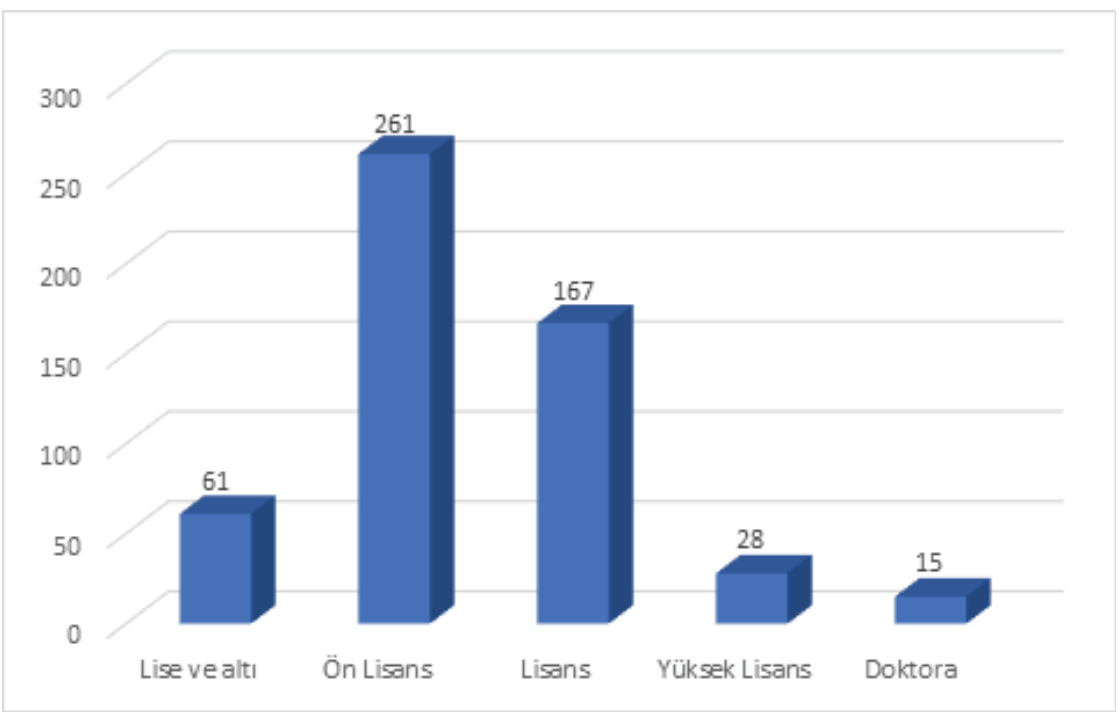


Çalışmaya katılım sağlayan kişilerin eğitim durumları Grafik 4'te görülmektedir. Katılımcıların yaklaşık \%50'sinin eğitim durumunun Ön Lisans, \%32'sinin eğitim durumunun ise Lisans olduğu görülmektedir. Katılımcıların eğitim durumları verileri Grafik 4 'te yer almaktadir.

\section{Grafik 5. Aylık Kişisel Gelir}

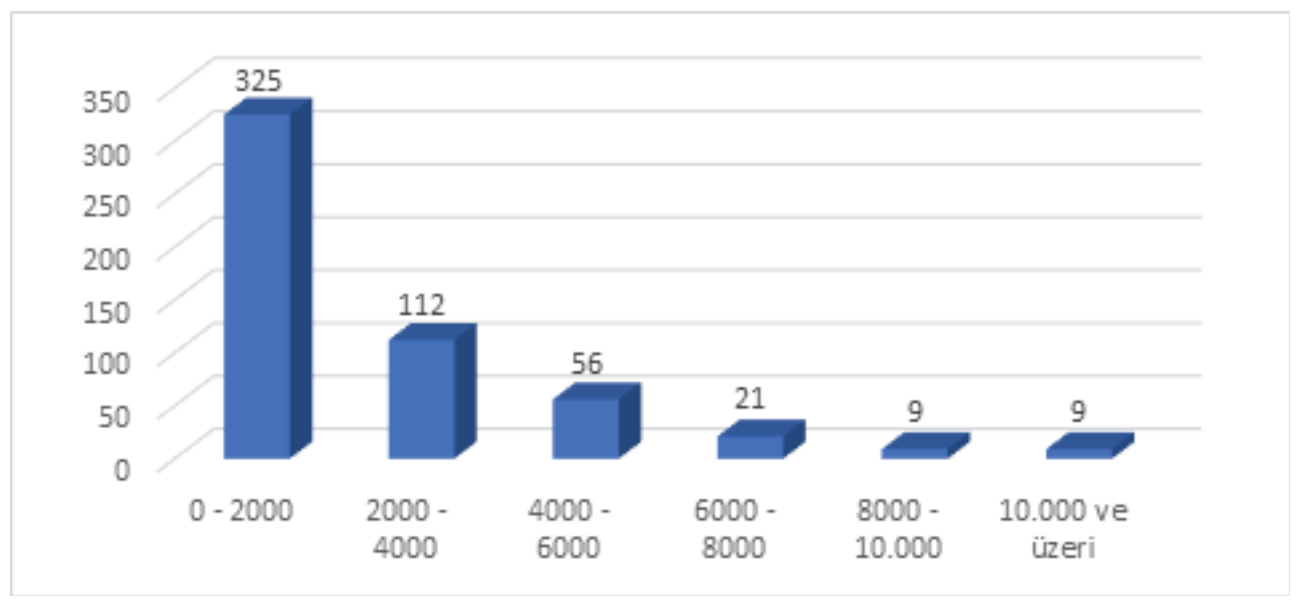

Grafik 5'e göre, katılımcıların \%61'inin aylık kişisel geliri 0-2000 TL aralı̆̆ında, \%21'inin 2000-4000 TL aralığında, \%11'inin 4000-6000 TL aralığındadır. Diğer kişisel gelir aralıkları verileri Grafik 5 'te yer almaktadır.

\section{Grafik 6. Aylık Kişisel Gelir Niteliği}

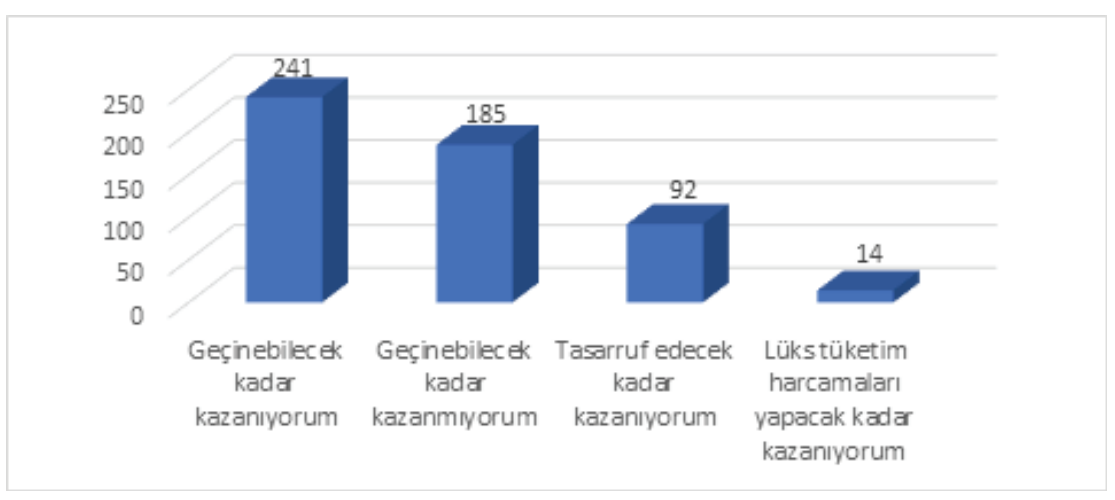

Katılımcıların aylık kişisel gelir niteliği Grafik 6'da yer almaktadır. Katılımcıların \%45'i geçinebilecek kadar kazanmakta, \%35'i geçinebilecek kadar kazanmamakta, \%17'si tasarruf edecek kadar kazanmakta ve \%3'ü lüks tüketim harcamaları yapacak kadar kazanmaktadır. 
Çalışmaya dahil edilen 532 yanıta, yatırımcıların hangi faktörlerden etkilenerek yatırım kararı verdiğinin tespiti amacıyla, SPSS programında istatistiksel yöntemler uygulanmıştır. Katılımcıların cevaplarına öncelikle faktör analizi uygulanmış ve katılımcıların en çok hangi anomali ve hevristiklerin etkisi altında yatırım kararı verdiğinin tespitini sağlanmaya çalışılmıştır. Daha sonra çalışmaya güvenilirlik analizi uygulanmıştır. Çalışma 25 sorudan oluşmuştur. Çalışmada sınama sorusu analize tabi tutulmamıştır. 7 sorunun ise faktör yükü yetersiz olduğu için analize tabi edilmemiş ve nihayetinde 17 soru ile analiz gerçekleştirilmiştir.

Çalışma kapsamında gerçekleştirilen veri toplama süreci neticesinde yanıtların ardındaki gizil yapıları keşfetmek amacıyla faktör analizi gerçekleştirilmiştir. Bu kapsamda öncelikle sorular arasındaki korelasyon matrisinin faktör analizine uygunluğunu incelemek amaciyla Kaiser-Meyer-Olkin ölçütü değeri hesaplanmış ve Bartlett's Küresellik Testi sonucu Tablo 1 'de sunulmuştur.

Tablo 1: KMO ve Bartlett's Test Sonuçları

\begin{tabular}{|c|c|c|}
\hline \multicolumn{2}{|c|}{ Kaiser-Meyer-Olkin Örneklem Yeterlilik Ölçütü } & ,910 \\
\hline \multirow[t]{2}{*}{ Bartlett Küresellik Testi } & Serbestlik Derecesi & 136 \\
\hline & Test İstatistiğinin Olasılık Değeri &, 000 \\
\hline
\end{tabular}

Tablo 1 incelendiğinde; KMO ölçütünün değeri ve Bartlett Küresellik Testi sonucu dikkate alındığında, faktör analizinin uygulanabileceğine karar verilmiştir. Tablo 1'de yer alan göstergelere bakıldığında, çalışmanın anlamlı ve ölçülen değerlerin yeterli olduğu görülmektedir.

Çalışmanın açıklanan varyans değerleri Tablo 2'de yer almaktadır. Tablo 2'ye bakıldığında, ilk üç faktörün, toplam değişkenliğin \%51,69’unu açıkladığı görülmektedir. Sosyal bilimlerde varyans oranının $\% 60$ ve daha az olabileceğinin kabul edileceği belirtilmektedir (Vieira, 2011). Gerçekleştirilen bazı çalışmalarda ise açıklanan varyansın \%40-\%60 aralığında olmasının da yeterli kabul edileceği savunulmaktadır (Scherer, Wiebe, Luther, \& Adams, 1988). Kaiser-Guttman kriterine göre de öz değeri birden büyük faktörler dikkate alınarak uygun faktör sayısı üç olarak belirlenmiştir. Açıklanan ilk üç faktörün varyansının faktörlere dağılımı da Tablo 3 'te yer almaktadır. 
Tablo 2: Açıklanan Varyans Tablosu

\begin{tabular}{|c|c|c|c|c|c|c|c|c|c|}
\hline \multirow{2}{*}{ Component } & \multicolumn{3}{|c|}{ Initial Eigenvalues } & \multicolumn{3}{|c|}{$\begin{array}{c}\text { Extraction Sums of Squared } \\
\text { Loadings }\end{array}$} & \multicolumn{3}{|c|}{$\begin{array}{c}\text { Rotation Sums of Squared } \\
\text { Loadings } \\
\end{array}$} \\
\hline & Total & $\begin{array}{c}\% \text { of } \\
\text { Variance }\end{array}$ & $\begin{array}{l}\text { Cumula- } \\
\text { tive } \%\end{array}$ & Total & $\begin{array}{c}\% \text { of } \\
\text { Variance }\end{array}$ & $\begin{array}{c}\text { Cumulative } \\
\%\end{array}$ & Total & $\begin{array}{c}\% \text { of } \\
\text { Variance }\end{array}$ & $\begin{array}{c}\text { Cumula- } \\
\text { tive } \%\end{array}$ \\
\hline 1 & 5,79 & 34,059 & 34,059 & 5,79 & 34,059 & 34,059 & 4,03 & 23,706 & 23,706 \\
\hline 2 & 1,617 & 9,514 & 43,573 & 1,617 & 9,514 & 43,573 & 2,944 & 17,316 & 41,021 \\
\hline 3 & 1,381 & 8,126 & 51,699 & 1,381 & 8,126 & 51,699 & 1,815 & 10,678 & 51,699 \\
\hline 4 & 0,864 & 5,083 & 56,782 & & & & & & \\
\hline 5 & 0,837 & 4,926 & 61,708 & & & & & & \\
\hline 6 & 0,766 & 4,508 & 66,217 & & & & & & \\
\hline 7 & 0,687 & 4,04 & 70,257 & & & & & & \\
\hline 8 & 0,655 & 3,855 & 74,112 & & & & & & \\
\hline 9 & 0,631 & 3,71 & 77,821 & & & & & & \\
\hline 10 & 0,593 & 3,489 & 81,31 & & & & & & \\
\hline 11 & 0,543 & 3,196 & 84,506 & & & & & & \\
\hline 12 & 0,518 & 3,046 & 87,552 & & & & & & \\
\hline 13 & 0,476 & 2,8 & 90,353 & & & & & & \\
\hline 14 & 0,449 & 2,642 & 92,994 & & & & & & \\
\hline 15 & 0,438 & 2,576 & 95,57 & & & & & & \\
\hline 16 & 0,403 & 2,368 & 97,938 & & & & & & \\
\hline 17 & 0,35 & 2,062 & 100 & & & & & & \\
\hline
\end{tabular}

Tablo 3: Faktör Dağılımları

\begin{tabular}{lccc}
\hline & \multicolumn{3}{c}{ Faktör } \\
\cline { 2 - 4 } & $\mathbf{1}$ & $\mathbf{2}$ & $\mathbf{3}$ \\
\cline { 2 - 4 } 21 & 0,77 & & \\
12 & 0,768 & & \\
13 & 0,674 & & \\
8 & 0,651 & & \\
20 & 0,627 & & \\
10 & 0,564 & & \\
22 & 0,553 & & \\
15 & 0,545 & & \\
23 & 0,544 & & \\
1 & & 0,782 & \\
3 & & 0,722 & \\
9 & & 0,684 & \\
7 & & 0,636 & \\
2 & & 0,578 & \\
24 & & & 0,717 \\
16 & & & 0,691 \\
5 & & & 0,521 \\
\hline
\end{tabular}


Çalışmada, 17 sorunun 3 faktöre dağıldığı gözlemlenmektedir. Bu faktörler bireylerin etkilendiği anomali ve hevristikleri ifade etmektedir. Bireylerin yatırım karalarını etkileyen birinci faktör, dışsal faktörler ve sürü davranışıdır. Dışsal faktörler yatırım kararlarından bağımsız olarak ortaya çıkan fakat bireyleri etkisine altına alan bir faktörlerdir. Sürü davranışı ise, bireyleri etkileyen ve bireylerin maruz kaldığı bir davranış olarak karşımıza çıkmaktadır. İkinci faktör, bilişsel yanılsamalardır. Bilişsel yanılsamalar, bireylerin psikolojik davranışlarından dolayı etkisi altında kaldığı ve yine yatırım kararlarında etkili olan bir faktördür. Üçüncü faktör ise yatırımcıların demografik ve sosyoekonomik özellikleridir. Yaş, cinsiyet, gelir durumu gibi özelliklerin de yatırım kararlarında etkili bir faktör olarak ortaya çıktığını görmek mümkündür. Yatırımcıların yatırım kararlarında dışsal faktörler ve sürü davranışı, bilişsel yanılsamalar ve demografik ve özellikler faktörlerinden etkilenerek yatırım kararlarında rasyonel olamadığı ve yatırım kararlarını bu üç faktörün etkisiyle doğru şekilde gerçekleştiremediği gözlemlenmektedir.

Güvenilirlik analizi, tekrarlanan ölçümlerde yanıtların tutarlılığını göstermektedir (Hair, Anderson, Tatham, \& Black, 2010). Sosyal ve davranışsal bilimlerde içsel tutarlılık katsayısı olarak yaygın şekilde Cronbach Alpha katsayısı kullanılmaktadır (Gizlier, 2018, s. 97-98). Bu katsayı, 0 ile 1 arasında değer almaktadır. Cronbach's Alpha katsayısı 1'e yaklaştıkça, ölçüm aracının güvenilirliği de o ölçüde artmaktadır. Ölçü aracının düzeyinin 0,70 ve üzerinde olmasının gerekliliği ifade edilmektedir (Cronbach, 1951).

Çalışmada, 17 soru analize tabi tutulmuş ve Cronbach〉s Alpha katsayısının 0,876 olduğu Tablo 4'te görülmektedir. Bu sonuca göre çalışmanın güvenilir düzeyde olduğu söylenebilmektedir.

Tablo 4: Güvenilirlik Analizi

\begin{tabular}{lc}
\hline \multicolumn{2}{l}{ Tüm Faktörlerin Güvenilirlik Düzeyi } \\
\hline Cronbach's Alpha & Soru Sayısı \\
,876 & 17 \\
& \\
\hline Dışsal Faktörler ve Sürü Davranışı Faktörü Güvenilirlik Düzeyi \\
\hline Cronbach's Alpha & Soru Sayısı \\
,853 & 9 \\
& \\
\hline Bilişsel Yanılsamalar Faktörü Güvenilirlik Düzeyi \\
\hline Cronbach's Alpha & Soru Sayısı \\
,778 & 5 \\
& \\
\hline Demografik ve Sosyoekonomik Özellikler Faktörü Güvenilirlik Düzeyi \\
\hline Cronbach's Alpha & Soru Sayısı \\
532 & 3 \\
\hline
\end{tabular}


Tüm faktörlerin güvenilirlik düzeyi yanında faktörlerin kendi içerisinde güvenilirliği de analiz edilmiştir. Bu sonuca göre 9 sorudan oluşan Dışsal Faktörler ve Sürü Davranışı faktörünün güvenilirlik düzeyinin 0,853, 5 sorudan oluşan Bilişsel Yanılsamalar faktörünün güvenilirlik düzeyinin 0,778 ve 3 sorudan oluşan Demografik ve Sosyoekonomik Özellikler faktörünün güvenilirlik düzeyinin 0,532 olduğu görülmektedir. Cronbach (1951)'e göre ölçü aracının güvenilirlik düzeyinin 0,70 olması gerektiği belirtilmiştir. Chakrapani (2004)'e göre de Cronbach Alpha katsayısının kabul edilebilecek sınırının 0,50'nin üzerinde olabileceği belirtilmiştir. Ayrıca Bowling (2014) ise az madde sayısının olduğu çalışmalarda kabul edilebilir sınırın en az 0,50 olmasının tutarlılık açısından yeterli olacağını ifade etmiştir. Dolayısıyla tüm faktörlerin güvenilirlik düzeyinin belirlenen sınırların üzerinde olduğu sonucuna ulaşılmıştır.

Tablo 5'te her bir katılımcı için ilgili faktörlere ait skorlar bulunmaktadır. Bu skorlara faktör skoru adı verilmektedir. Toplam üç faktör skoru değişken olarak alınmış ve bu değişkenler arasında Pearson Korelasyon katsayısı hesaplamıştır. Analiz sonuçları Tablo 5 'te yer almaktadır.

Tablo 5: Faktörler Arası Korelasyon

\begin{tabular}{|c|c|c|c|c|}
\hline & & $\begin{array}{l}\text { Dışsal Faktörler ve } \\
\text { Sürü Davranışı }\end{array}$ & $\begin{array}{c}\text { Bilişsel } \\
\text { Yanılsamalar }\end{array}$ & $\begin{array}{c}\text { Demografik ve } \\
\text { Sosyoekonomik } \\
\text { Özellikler }\end{array}$ \\
\hline \multirow{3}{*}{$\begin{array}{l}\text { Dişsal Faktörler ve } \\
\text { Sürü Davranış1 }\end{array}$} & Pearson Korelasyon & 1 &, $548^{* *}$ &, $391^{* *}$ \\
\hline & $\begin{array}{c}\text { Çift Yönlü Test } \\
\text { İstatistiğinin Olasıllk } \\
\text { Değeri }\end{array}$ & & ,000 & ,000 \\
\hline & Gözlem Sayısı & 532 & 532 & 532 \\
\hline \multirow{3}{*}{ Bilişsel Yanılsamalar } & Pearson Korelasyon &, $548^{* *}$ & 1 &, $398^{* *}$ \\
\hline & $\begin{array}{c}\text { Çift Yönlü Test } \\
\text { İstatistiğinin Olasıllk } \\
\text { Değeri }\end{array}$ &, 000 & &, 000 \\
\hline & Gözlem Sayıs1 & 532 & 532 & 532 \\
\hline \multirow{3}{*}{$\begin{array}{l}\text { Demografik ve } \\
\text { Sosyoekonomik } \\
\text { özellikler }\end{array}$} & Pearson Korelasyon &, $391^{* *}$ &, $398^{* *}$ & 1 \\
\hline & $\begin{array}{c}\text { Çift Yönlü Test } \\
\text { İstatistiğinin Olasılık } \\
\text { Değeri }\end{array}$ & ,000 &, 000 & \\
\hline & Gözlem Sayısı & 532 & 532 & 532 \\
\hline
\end{tabular}

Pearson Korelasyon katsayısının hesaplanması, çalışmanın geçerlilik özelliğini raporlamak adına önem arz etmektedir. Faktörler arasında 0,54, 0,39 ve 0,39 olmak üzere anlamlı ve pozitif yönlü bir ilişkinin varlığından bahsedilebilmektedir. Faktörler arası korelasyonlar 0,60'dan küçük olduğu için, boyutlar birbirinin alanına girmemiş ve boyutların her biri ölçmek istenilen hususu ölçmüştür sonucuna ulaşılmaktadır. Sonuç olarak bu soru formu ile toplanan veri kümesinin geçerli ve güvenilir olduğu anlaşılmaktadır. 


\section{Sonuç}

Davranışsal finans, geleneksel finans teorilerinin aksine, yatırımcıların vermiş oldukları yatırım kararlarında rasyonel olmadığını ve yatırım kararlarında çeşitli anomali ve hevristikler nedeniyle yanlış kararlar verdiğini savunmaktadır. Davranışsal finans psikoloji, sosyoloji gibi bilimlerle ekonominin bir araya getirilmesiyle oluşmuş ve geleneksel finans teorilerinin aksine literatüre yatırımcı davranışı kavramını kazandırmıştır. Davranışsal finans yatırımcıların psikolojik, dışsal, bilişsel gibi çeşitli faktörlerin etkisiyle rasyonel olamadığını savunmaktadır. Bu çalışmanın amacı, bireylerin rasyonel olamama nedenlerinin hangi faktörlere bağlı olduğunu ortaya çıkarmaktır. Çalışmada yöntem olarak 25 soruluk anket çalışması uygulanmış ve 5'li likert ölçeği kullanılmıştır. Çalışmaya katılım sağlayan 685 kişiden 138 kullanıcı sınama sorusunu yanlış cevapladığı için, 15 katılımcı ise bütün sorulara aynı yanıtı verdiği için analize dahil edilmemiş ve 532 katılımının cevabı SPSS programında analiz edilmiştir. Verilere öncelikle Faktör Analizi uygulanarak 25 soru içerisinde, 7 sorunun faktör yükünün yetersiz olduğu tespit edilmiştir. Mevcut sorulardan 7 soru ve sinama sorusu çıkarılarak, analize faktör yükü yeterli olan 17 soru dahil edilmiştir. Toplam açıklanan varyansa bakıldığında ise tüm faktörlerin \%51,69’luk bir açıklama gücüne sahip olduğu gözlemlenmiştir. 17 soru analize tabi edilmiş ve belirli faktörlerde toplanması sağlanmıştır. Daha sonra yanıtlara güvenilirlik analizi uygulanmıştır. Güvenilirlik analizi sonucunda Cronbach's Alpha katsayısının 0,876 olduğu görülmüş ve çalışmanın güvenilir olduğu sonucuna ulaşılmıştır. Çalışmada KMO değerinin ise 0,91 olduğu tespit edilmiş ve belirlenen sınırın üzerinde bir sonuç alınmıştır. Çalışmada faktörlerin güvenilirlik düzeyinin yeterli olduğu görülmüştür. Ayrıca faktörler arasında anlamlı ve pozitif yönlü ilişkinin varlığı da tespit edilmiştir. Çalışma sonucunda, yatırımcıların yatırım kararlarında maruz kaldığ durumlar, üç faktörde toplanmıştır. Bu faktörler dışsal faktörler ve sürü davranışı, bilişsel yanılsamalar, demografik ve sosyoekonomik özelliklerdir. Dışsal faktörler, yatırımcıların yatırım esnasında etki altında kaldığı ve kendileriyle ilişkisiz faktörleri temsil etmektedir. $\mathrm{Bu}$ faktörler haftanın günleri etkisi, hava koşulları etkisi, bayram, kutsal günler, tatil ve ay etkisi şeklinde sıralanmaktadır. Yatırımcıların yatırım kararı verirken bu faktörlerden ve aynı anda, aynı piyasada ve aynı yönlü işlemleri ifade eden sürü davranışından etkilenerek yatırım yaptığı tek bir faktörde toplanmıştır. Yatırımcıların etkilendiği bir diğer faktör psikolojik durumları içeren bilişsel yanılsamalardır. Bilişsel yanılsamalar aşina olma, aşırı reaksiyon, iyimserlik, aşırı güven gibi sezgisel yanılsamaları ve pişmanlıktan kaçınma, zihinsel muhasebe, çerçeveleme etkisi gibi zihinsel yanılsamaları kapsamaktadır. Katılımcıların demografik ve sosyoekonomik özelliklerinin de yatırım kararlarında etkili olan diğer faktör olduğu sonucuna ulaşılmıştır. Yatırımcıların demografik ve sosyoekonomik özellikleri ise yaş, cinsiyet, medeni durum, eğitim seviyesi, meslek ve gelir seviyesi gibi faktörlerdir. Çalışmada bireylerin, yatırım kararlarında tespit edilen üç faktörlerden etkilenerek yatırım kararlarını verdiği tespit edilmiştir. Çalışmanın, büyük bir kısmının benzer yaş gruplarına uygulanması sınırlılık olarak gösterilebilir. Farklı yaş ve gelir gruplarına çalışma gerçekleştirmek öneri olarak sunulmaktadır. 
Etik Komite Onayı: İstanbul Ayvansaray Üniversitesi Akademik Araştırma ve Yayın Etiği Kurulundan etik komite onayı alınmıştır. (23/02/2021 - E-31675095-299-2100001362)

Bilgilendirilmiş Onam: Katılımcılardan bilgilendirilmiş onam alınmıştır.

Hakem Değerlendirmesi: Dış bağımsız.

Yazar Katkıları: Çalışma Konsepti/Tasarım- B.M., A.S.; Veri Toplama- B.M., A.S.; Veri Analizi/Yorumlama- B.M., A.S.; Yazı

Taslağ1- B.M., A.S.; İçeriğin Eleştirel İncelemesi- B.M., A.S.; Son Onay ve Sorumluluk- B.M., A.S.

Çıkar Çatışması: Yazarlar çıkar çatışması beyan etmemişlerdir.

Finansal Destek: Yazarlar finansal destek beyan etmemişlerdir.

Ethics Committee Approval: This study was approved by the Academic Research and Publication Ethics Committee of İstanbul Ayvansaray University. (23/02/2021 - E-31675095-299-2100001362)

Informed Consent: Written consent was obtained from the participants.

Peer Review: Externally peer-reviewed.

Author Contributions: Conception/Design of Study- B.M., A.S.; Data Acquisition- B.M., A.S.; Data Analysis/Interpretation- B.M., A.S. ; Drafting Manuscript- B.M., A.S.; Critical Revision of Manuscript- B.M., A.S.; Final Approval and Accountability- B.M., A.S. Conflict of Interest: Authors declared no conflict of interest.

Financial Disclosure: Authors declared no financial support.

\section{Kaynakça/References}

Altay, E. (2008). Sermaye piyasasında sürü davranışı: İmkb’de piyasa yönünde sürü davranışının analizi. $B D D K$ Bankacilı ve Finansal Piyasalar Dergisi, 2(1), 27-58.

Aren, S. (2018). Davranışsal finansa kuramsal bakış. Eskişehir Osmangazi Üniversitesi İIBF Dergisi, 13(3), 141160.

Aydın, Ü., \& Ağan, B. (2016). Rasyonel olmayan kararların finansal yatırım tercihleri üzerindeki etkisi: Davranışsal finans çerçevesinde bir uygulama. Ekonomik ve Sosyal Araştırmalar Dergisi, 12(2), 95-112.

Barak, O. (2008). İMKB'de Aşırı reaksiyon anomalisi ve davranışsal finans modelleri kapsamında değerlendirilmesi. Gazi Üniversitesi İktisadi ve İdari Bilimler Fakültesi Dergisi, 10(1), 207 - 229.

Bowling, A. (2014). Research methods in health: Investigating health and health services. New York: McGraw-Hill Education.

Chakrapani, C. (2004). Statistics in market research. London: Arnold Publisher.

Cronbach, L. (1951). Coefficient alpha and the internal structure of tests. Psychometrika, 16(3), 297-334.

Çetiner, M., Ayhan Gökcek, H., \& Turp Gölbaşı, B. (2019). Davranışsal finans perspektifinden yatırımcı davranışları üzerine bir inceleme. Uluslararası Bankacılık, Ekonomi ve Yönetim Araştırmaları Dergisi, 2(1), 1-30.

Doğukanlı, H., \& Ergün, B. (2011). Davranışsal finans etkin piyasalara karşı: aşırı tepki hipotezinin İMKB'de araştırılması. Ç. ̈. Sosyal Bilimler Enstitüsü Dergisi, 20(1), 321-336.

Fama, E. (1970). Efficient capital markets: A Review of theory and empirical work. The Journal of Finance, 25(2), $383-417$.

Genç, M. (2019). Sakarya ili çalışan kesimin yatırım kararlarının davranışsal finans açısından değerlendirilmesi. Uluslararası Ekonomik Araştırmalar Dergisi, 5(1), 49-59.

Gül, M., Ekşi, İ. H., \& Sürme, M. (2017). Davranışsal finans açısından altın yatırımıılarının davranışlarının incelenmesi: Gaziantep Örneği. Maliye Finans Yazıları(108), 143-166.

Gümüş, F. B., Koç, M., \& Agalarova, M. (2013). Bireysel yatırımcıların yatırım kararları üzerinde etkili olan demografik ve psikolojik faktörlerin tespiti üzerine bir çalışma: Türkiye Ve Azerbaycan uygulaması. Kafkas Üniversitesi İktisadi ve İdari Bilimler Fakültesi Dergisi, 4(6), 71-93. 
Gümüş, G., \& Bektur, Ç. (2019). Etkin piyasa hipotezi ve davranışsal finans modelleri, BİST-100 endeksinde anomali testi. Uluslararası Ekonomik Araştırmalar Dergisi, 5(2), 59-69.

Hair, J., Anderson, R., Tatham, R., \& Black, W. (2010). Multivariate data analysis. New Jersey: Prentice Hall.

Hall, R. (1978). Stochastic implications of the life cycle-permanent income hypothesis: Theory and evidence. Journal of Political Economy, 86(6), 971-987.

Kahneman, D., \& Tversky, A. (1979). Prospect theory: An analysis of decision under risk. Econometrica, 47(2), 263-292.

Korkmaz, T., \& Ceylan, A. (2017). Semaye piyasası ve menkul değer analizi. Bursa : Ekin Basım Yayın Dağıtım.

Küçük, A. (2014). Bireysel yatırımcıları finansal yatırım kararına yönlendiren faktörlerin davranışsal finans açısından ele alınması: Osmaniye örneği. Akademik Araştırmalar ve Çalışmalar Dergisi(11), 104-122.

Mola, H. (2021). Davranışsal iktisat perspektifinden iktisadi karar alma sürecinde gizli tuzaklar ve dürtmeler. Oltu Beşeri ve Sosyal Bilimler Fakültesi Dergisi, 2(1), 20-35.

Özer, A., \& Korkulutaş, D. (2018). Yatırımcıların duygusal ve bilişsel eğilimlerinin değerlendirilmesi: Erzincan ili uygulaması. Kafkas Üniversitesi İktisadi ve İdari Bilimler Fakültesi Dergisi, 9(18), 391-420.

Scherer, R., Wiebe, F., Luther, D., \& Adams, J. (1988). Dimensionality of coping: Factor stability using the ways of coping questionnaire. Psychological Reports, 62(3), 763-770.

Tekin, B. (2018). Bilişsel önyargı ve hevristik bağlamında finansın insani boyutu olarak "Davranışsal Finans": Bir literatür incelemesi ve derleme çalışması. Uluslararası İnsan Çalışmaları Dergisi, 1(2), 131-156.

Tufan, C., \& Sarıçiçek, R. (2013). Davranışsal finans modelleri, etkin piyasa hipotezi ve anomalilerine ilişkin bir değerlendirme. Trakya Üniversitesi Sosyal Bilimler Dergisi, 15(2), 159-182.

Türkmen Müldür, G. (2018). Geleneksel ve davranışsal finans: tarihsel ve kavramsal çerçeve. Adana Alparslan Türkeş Bilim ve Teknoloji Üniversitesi Sosyal Bilimler Dergisi, 2(1), 37-45.

Vieira, A. L. (2011). Interactive LISREL in Practice: Getting Started with a SIMPLIS Approach. London New York: Springer Heidelberg Dordrecht. 


\section{EK 1}

\section{YATIRIMLARDA DAVRANIŞSAL FINANS EĞILIIMINİ ÖLÇME VE DEĞERLENDİRME ANKETI}

\section{Değerli katılımc1,}

Davranışsal Finans, bireylerin yatırım kararı verirken birtakım psikolojik ve sosyal faktörlerin etkisinde kalarak bu kararları doğru şekilde verememesinin nedenlerini açıklamaktadır. Geleneksel finans teorileri aksine davranışsal finans, bütün bireylerin rasyonel olmadığını ve yatırım kararlarını esnasında maruz kaldığı faktörler nedeniyle yatırım kararlarını doğru bir şekilde veremediğini savunmaktadır.

$\mathrm{Bu}$ çalışma son yıllarda geleneksel finans teorilerinden farklı olarak bireylerin yatırım kararı verirken maruz kaldığı faktörleri ölçmek ve davranışsal finansın bireylerin yatırım kararları üzerindeki etkisini anlamak amacıyla hazırlanmıştır.

Katılımınız için teşekkür ederiz.

Doç. Dr. Arif SALDANLI saldanli@istanbul.edu.tr

Öğr. Gör. Batuhan MEDETOĞLU batuhanmedetoglu@ayvansaray.edu.tr 


\begin{tabular}{|c|c|c|c|}
\hline \multicolumn{4}{|c|}{ BİRİNCİ BÖLÜM } \\
\hline \multirow{2}{*}{ Cinsiyet } & Erkek ( ) & \multirow{5}{*}{$\begin{array}{l}\text { Eğitim } \\
\text { Durumu }\end{array}$} & Lise ve altı ( ) \\
\hline & Kadın ( ) & & Ön lisans ( ) \\
\hline \multirow{8}{*}{ Yaş Aralığı } & $18-24()$ & & Lisans ( ) \\
\hline & & & Yüksek Lisans ( ) \\
\hline & $25-29(\quad)$ & & Doktora ( ) \\
\hline & $30-34(\quad)$ & \multirow{4}{*}{$\begin{array}{l}\text { Aylık } \\
\text { Kişisel Gelir } \\
\text { Niteliğiniz }\end{array}$} & Geçinebilecek Kadar Kazanmıyorum ( ) \\
\hline & $35-39(\quad)$ & & Geçinebilecek Kadar Kazanıyorum ( ） \\
\hline & $40-44(\quad)$ & & Tasarruf edecek kadar kazaniyorum ( ） \\
\hline & $45-49(\quad)$ & & $\begin{array}{l}\text { Lüks tüketim harcamaları yapacak } \\
\text { kadar kazanıorum ( ) }\end{array}$ \\
\hline & $50+(\quad)$ & \multirow{6}{*}{$\begin{array}{l}\text { Aylık Kişisel } \\
\text { Geliriniz }\end{array}$} & $0-2000(\quad)$ \\
\hline \multirow{5}{*}{ Çalışma Durumu } & Öğrenci ( ） & & $2000-4000(\quad)$ \\
\hline & Ev hanımı ( ) & & $4000-6000(\quad)$ \\
\hline & Emekli ( ) & & $6000-8000(\quad)$ \\
\hline & $\begin{array}{l}\text { Çalışmiyorum } \\
(\mathrm{C}\end{array}$ & & $8000-10000(\quad)$ \\
\hline & Çalışıyorum ( ) & & 10000 ve üzeri ( ) \\
\hline
\end{tabular}

\section{İKİNCİ BÖLÜM}

Bu bölümde davranışsal finans eğiliminizi ölçmek amacıyla çeşitli sorular verilmiştir. Lütfen bu soruları kendi düşünceleriniz doğrultusunda;

1-Kesinlikle Katılmıyorum, 2-Katılmıyorum, 3-Kararsızım, 4-Katılıyorum, 5-Kesinlikle Katılıyorum, seçeneklerinden birini seçerek cevaplandırınız.

\begin{tabular}{|c|c|c|c|c|c|c|}
\hline $\begin{array}{l}\text { Soru } \\
\text { No }\end{array}$ & SORULAR & 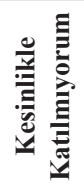 & 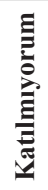 & 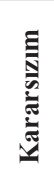 & 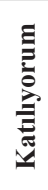 & 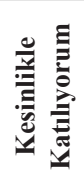 \\
\hline 1 & $\begin{array}{l}\text { Yapacağım yatırımlarda kendime güvenirim, zarar } \\
\text { etme ihtimalim çok düşüktür. }\end{array}$ & & & & & \\
\hline 2 & $\begin{array}{c}\text { Yapacağım yatırımlarda aşina olduğum şirket, } \\
\text { yabancı para ya da kurum üzerine yatırım kararı } \\
\text { veririm. } 10\end{array}$ & & & & & \\
\hline 3 & $\begin{array}{l}\text { Başarılı olduğum yatırımlar, vermiş olduğum } \\
\text { doğru kararların sonucunda gerçekleşmiştir. }\end{array}$ & & & & & \\
\hline 4 & $\begin{array}{l}\text { Yatırımlarımda analiz yapmak yerine, finansal } \\
\text { varlıklarının hareketliliğine bakarak karar veririm. }\end{array}$ & & & & & \\
\hline 5 & $\begin{array}{c}\text { Sahip olduğum varlığın fiyatında bir değişiklik } \\
\text { olduğunda, genellikle hemen varlığı satmayıp } \\
\text { fiyatınnn yükselmesini beklerim. }\end{array}$ & & & & & \\
\hline 6 & $\begin{array}{l}\text { Aynı tutardaki kâra ve zarara maruz kaldığımda, } \\
\text { zarara kârdan daha fazla duyarlıyımdır. }\end{array}$ & & & & & \\
\hline
\end{tabular}




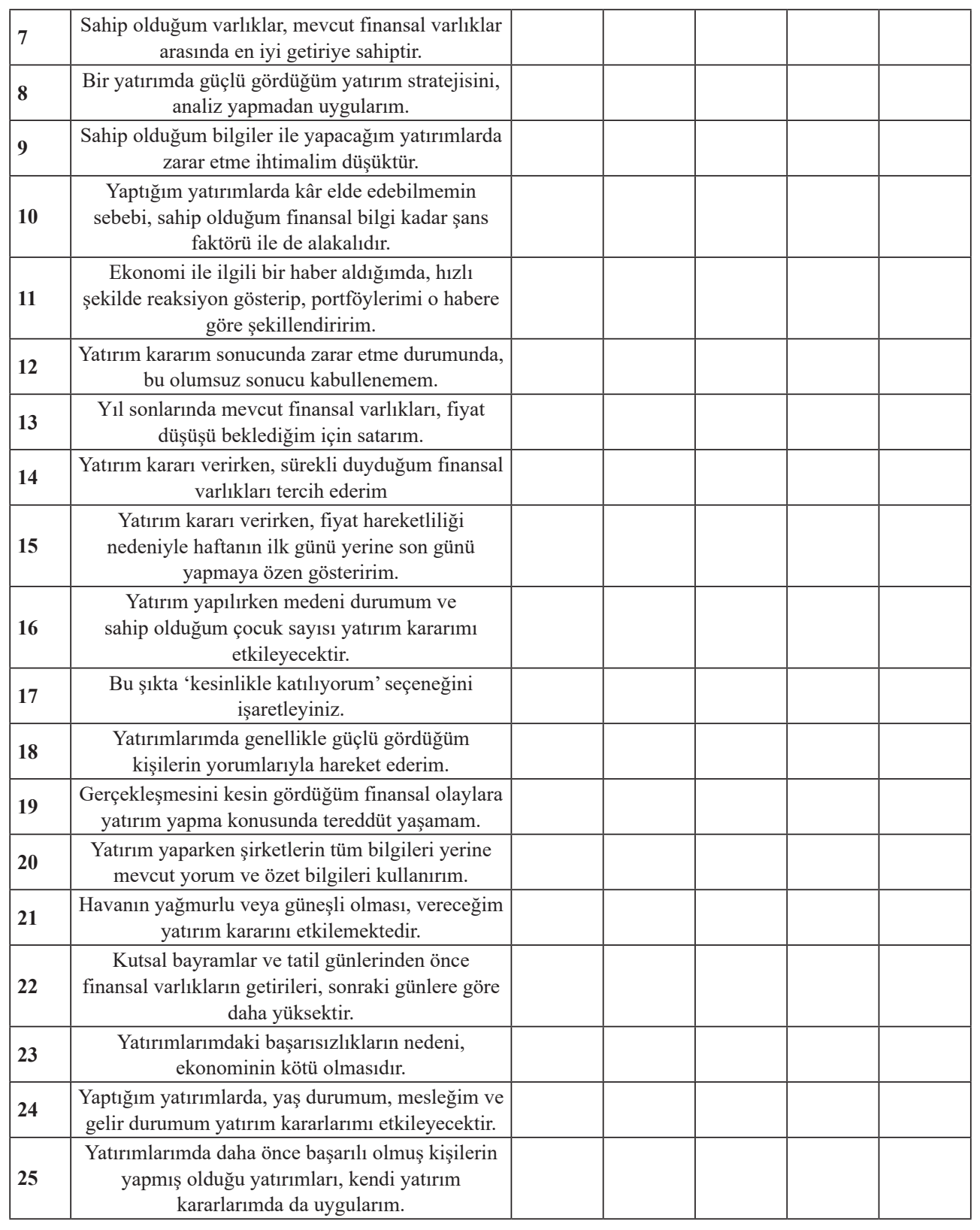

